\title{
COMMERCIAL BANK BEHAVIOR AND MONETARY POLICY IN AN OPEN ECONOMY
}

\author{
West Germany 1960-1980* \\ Rudolf RICHTER \\ University of the Saarland, 66 Saurbr ücken, West German!' \\ Ronald L. TEIGEN \\ The University of Michigan, Ann Arbor, MI 48J09, US.4
}

\begin{abstract}
This paper studies movements in the ratio of free liquid reserves of West German commercial banks to total deposits over the period 1960-1980. The desired ratio is assumed to depend positively on the 'own yield', measured by recently experienced variance of the required-reserve ratio (a proxy for portfolio adjustment costs avoided by holding (ree reserves), and negatively on the yield on alternative assets. The observed free reserve ratio also responds to changes in the Bundesbank's holdings of foreign exchange and net government deposits. Empirical tests on quarterly data support the hypothesis, though behavioral shifts occurred in 1966 and 1973.
\end{abstract}

\section{Introduction}

In examining the money s ipply process and the functioning of monetary policy in the Federal Republic of Germany in the last twenty years, the free liquid reserves of commercial banks are of central importance. Factors leading banks to adjust their desired level of free reserves relative to deposits, as well as those influcinces causing the actuai free reserve ratio to deviate from its desircd level, result ceteris paribus in inoney stock changes. Furthermore, the Bundesbank has regarded the commercial banks' reserve position as a proximate target for monetary policy during much of the period studied.

In this paper, we investigate the causes of movements in the free liquid reserve position of West German commercial banks during 1960-1980. Uur work builds on the recent study by Richter, McMahon and Regier (1978), but differs most importantly in that we successfully introduce a novel behavio al variable - - a moving variance - to measure banks' anticipations

Much of the work on this pays was done when the latter atthor was Richard Merton Visiting Professor at the University of the Saarland in 1979. We are indebted to the Deutsche Forschungsgemeinschaft for financial surwort and to the Deutsche Bundesbank for data and advice. Norbert Juchem gave us valuable assistance in data gathering, processing and computation. For comments and suggestions we wish particularly 10 thank Dietrich Lüdeke, Patrick McMahon, and trans Schnceweiss. 
concerning movements in the average required reserve ratio and hence the benefits of maintainiris a given free reserve position. This innovation enables us to use a single behavioral hypothesis to explain movements in the free reserve ratio over the whole period 1960-1980. In contrast, Richter et al. employed two somewhat different specifications for the subperiods 1960-1966 and 1966-1972, and they did not investigate behavior in the post-Bretton Woods years $1973-1980$ at all. We find, as they did, that some structural change occurred during the period studied.

\section{Institutiongl background}

Free liquid reserves initially were defined by the Deutsche Bundesbanix to consist of commercial bank excess reserves, plus certain assets which the banks could convert into cantral bank rescrve deposits at their initiative but on terms set by the Bunjesibank (specifically, domestic and foreign-currencydenominated money market paper), plus the unused part of the redisciount quota set by the Bundesbank for the commercial banks, less borrowing fron the Bundesbank with securities as collateral ('lombarding'). ${ }^{1}$ Following the collapse of the fixed-exchange-rate system in 1973, bank holdings of foreign money market instruments were dropped from the definition since the Bundesbank no longer was obliged to buy them, when offered, to defend the exchange rate. In 1973, furthermore, the Bundesbank shifted its focus from net free reserves as defined above to a gross concept in which lombarding was disregarded, and it began to report monthly average rather than end-ofmonth free reserves data. In this study, we have followed the Bundesbank in omitting bank foreign money market claims beginning in 1973; but we have chosen to net out lombarding over the whole period for reasons discussed in footnote 9 below, and we also have used end-of-month data throughc?t to preserve comparatibility. ${ }^{2}$

Over the period studied, the Bundesbank has attempted to influence the quantity and terrns of bank credit by using its instruments of control to affert the level of free reserves. These in"truments have included rediscount quotas and rates; the quantity of money market paper available and the ternıs on which it could be bought and sold; and, most importantly, the

\footnotetext{
'For a detailed definition of the specific securities included in ench of thesa categories, see Inst "uments of Monetary Policy in the Federal Republic of Germany, Deutsche Bundesbank, 1971. p. 19.

2"Neuabgrenzung der 'freien Liquiditätsreserven' der Banken', Monarsberichte der Diatschen Bundesbank, Juni 1973, pp. 47-48. See also Die währungspolitischen Invtitutionen und Insli umente in der Bundesrepublik Deutschland, Deutsche Bundesbank, März 1980, p. 27. Complete definitions of free liquid reserves in the two periods are contaned in the appendix to this paper. Nolice that in our calculation of net free reserves for 1973-1980 we have also deducted the newly-included category 'trade bills bought under repurchase agreements on the open market' as well as !ombard loans because we consider this to be in effect another kind of borrowed reserve.
} 
schedule of reserve requirements for bank deposits. ${ }^{3}$ Changes in this schedule affect free liquid reserves directly by altering the amounts of excess and required reserves held by the banks, Howerer, there are potential points of slippage in the Bundesbank's ability to control free reserves closely. During the fixed-exchange-rate period, for example, free reserves increased when the Bundesbank was obliged to purchase dollars to defend the fixed dollar/DM rate; and while it tried to use other means to offset this expansion, such as reserve requirement changes, those measures usually were not very successful. ${ }^{4}$ Even though this obligation no longer exists, the Bundesbank's foreign exchange operations may still affect free reserves. Changes in deposits of subsidiary governmental units at the Bundesbank will also affect bank liquidity if offsetting action is not taken. As will be seen, we have included these considerations in our work. Finally, it has been the Bundesbank's practice to provide short-run accommodation in response to shifts in the banks' demand for base money, via, e.g., increasing the amount of advances on securities (lombard loans) outstanding. However, such accommodation reduces the level of net free reseives, the measure used consistently in our si.udy, ${ }^{5}$ and there will likely ensue corrective adjustments in bank portfolios such that there may not result very much long-run slippage. ${ }^{6}$

\footnotetext{
"The Bundesbank's most important instrument for influencing the liquidity of the banks is the : inimum reserve requirement.' 'Notes on the Bundesbank's Liquidity Analysis', Monthly Report of the Deutsche Bundesbe $k$. July 1970, p. 29.

${ }^{4} \mathrm{Cr}$. Instruments of Monetary Policy..., 1971, pp. 29-30. As mentioned in footnote 19 below, there is almost no correation between change in the B-sudesbank's holdings of foreign exchange and the reserve ratio of the conmercial banks over the period studied.

'In netting borrowings against gross free reserves, we are following the procedure used in several other studies. See, e.g., Meigs $(1962$, p. 3), and for an historical overview, see Cagan (1969, pp. 267ii). Cf. footn ote 9 below for a further discussion of net vs. gross free reserves.

'Before 1970, lombarding was of relatively minor importance, but thereafter its use grew rapidly, and various measures were initiated by the Bundesbank as a consequence. In the autunin of 1970, it introduced a "ombard margin" equal to 20 percent of a bank's rediscount quota. On May 30, 1973, the Bundesbank seased providing lombard loans altogether, as part of its effort to reduce frec reserves substantially and to shift the focus of monetary policy from free reserves to the direct control of the creation of central bank money (cf. Report of the Deutsche Bundesbank for the Year 1973, p. 3). But late in 1973 it began providing 'special lombard credits' and as of July 23, 1974 it began granting ordinary lombard credits without restriction. In response, commercial bank usage of this facility grew very rapidly, and from September 1979 to February 1980 the Bundesbank reintroduced a 'lombard margin' equal to 15 percent of a bank's rediscount quota. As of February 19, 1981, the Bundesbank again stopped making ordinary lombard credit available but made provision for special lombard credits. Through all of these changes, it has held that lombard loans are not a pcrmanent source of bank funds but rather are simply a means for bridging temporary liquidity shortages and has stated. 'The banks ha 'e no general claim to refinancing by the Bundestank... Whether an advance on securities [i.e., a lombard loan] is granted depends on th general credit situation and the situation of the individual borrower. In principle the Bundesbank grants an advance on securities only when it is required to bridge temporary liquidity difficulties, and when the Bank has no objections to the purzoses to which the advence is to be applied. Instruments of Monetary Policy..., 1971, pp. 29 and 33 .
} 


\section{The free liquidity ratio: $\mathbf{A}$ behavioral hypothesis}

Let us begin by defining the free liquidity ratio $\lambda=F R / D T S F$, where $F R$ is total commercial bank net free liquid reserves as defined earlier and DTSF is the sum of demand, saving, time, and foreign deposits held by the commercial banking system. In our work, DTSF is used as the scaling variable instead of total bank assets because of the unavailability of a consistent data series for the latter variable over the time period covered by this study. ${ }^{7}$ To explain movements in this ratio, we follow the standard wealth-allocation paradigm: the desired free reserve ratio $\lambda^{*}$ should depend positively on the 'own yield' on free reserves and inversely on the yields on alternative portfolio components (bonds, business loans). The main innevation of the present study is the approach taken to the definition and measurement of these yields, particularly the 'own yield' on free reserves which we will discuss next.

\section{3.' The 'own yield' on free reserves}

While some of the components of the free reserves definition pay explicit yields, it is our conjecture that the relatively low market rates of return characteristic of these assets do not provide adequate incentives for the banks to maintain their observed free reserve positions. ${ }^{8}$ If banks faced no uncertainty concerning the near-term fut dre, particularly as regards the required reserve ratio, they would probably hold very modest amounts of gross free reserves relative to deposits and possibly would be willing to borrow very heavily (if they were allowed to do so) so that their net free reserves might typically be well below zero.

However, unexpected changes in the required reserve ratio - the Bundesbank's most actively used policy instrument - or in other factors influencing free reserves can impose heavy adjustment costs on vulnerable banks in the form of forced changes in loans and in holdings of bonds and other assets; and under this kind of uncertainty, together with some reluctance and/or inability to extend their borrowing indefinitely, banks may well find it rational to increase their free reserve holdings over the position they would maintain under certainty. ${ }^{9}$ Furthermore, the greater the amount

\footnotetext{
${ }^{7}$ As of April 1969, balance sheet data for building associations and some other financial institutions were added to the financial statistics, creating a discrepancy in the data on total bank assets.

${ }^{8}$ Sorne studis on cirmmercial bank behavior in the Federal Republic have used various shortterm interest rates to measure the 'own yield' of free reserves. In Richter et al (1978) the threemonth loan rate is employed, while in König et al (1977) the Bundesbank selling rate for open marke papers is a determinant of commercial bank holdings of these pipers.

'Notice that there is no inconsistency hetween our basic concept of free reserves as a buffer against unexpected reserve requirement changes and other stocks and our use of net free reserves - which may be negative wi'sn borrowings are large -- rather than gross free reserves
} 
of uncertainty, the more highly banks will tend to value a given free reserve position, and the more free reserves are likely to be held relative to other assets. Therefore we define the 'own yield' for a given free reserve position as the banking system's subjective expectation, over the planning horizon, of the revenue loss which car be avoided by maintaining that position. ${ }^{10}$

This expectation cannot be observed directly, so an important question for our empirical work is how to quantify it adequately. The effective reserve ratio changes on account of both policy initiatives of the Bundesbank (which made 54 changes during $1960-1980)^{1.1}$ and shifts of deposits among categories subject to differing reserve requirements. Its movements from 1960 to 1980 are shown in fig. 1. In such an environment, it is intuitively appealing as well as consistent with other recent woik to suppose that banks refer to their recent past experience in forming expectations of this kind. ${ }^{12,13}$

as the focus of our study. Indeed, the possibility of borrowing, if it exists, is one of the safety valves atailable to banks. However, as indicated in: footnote 6 above, there are definite linnits on the amount of botrowing which the Bundesbank will permit (and sometimes this limit may theoretically be zero), anc it is probably also the case that the banks become increasingly reluctant to borrow, the larger are their existing borrowings. Therefore we argue that net free reserves are a more una nbiguous measure of the barks' licuidity position than gross free reserves, because a given amount of the latter could correspond to any number of net free reserve positions for dife ent levels of borrowing. In particular, we hold that there is nothing uniquely meaningul abo st a zero level of gross frce reserves, as the Bundesbank seems to believe.

${ }^{10}$ Note that, in a world of uncertainty, banks would probably find it advantageous to increase their net free reserve holdings as compared to the certainty case even if a given reserve ratio now is viewed as the mean of a symmetric subjective probability distribution cier possible future reserve ratios. In other words, they now find it to their advantage to hold more net free reserves relative to deposits even if reductions in the existing ratio are thought to be just as likely as increases. This only requires that the adjustment costs imposed by increase: in the ratio are greater than those imposed by decreases, as set:ms very likel: .

"For details, see 'Verzeichnis der in der Zeit vom Januar 1060 bis Dejember 1979 in den 'Monatsberıchten der Deutschen Bundesbank' ers shienenen Sonderaufsätze und Kommentare zu Kreditpolitischen Maßnahmen', pp. 9f in Monatsherichte der Deutschen Bundesbank, December 1980 (supplement).

${ }^{12}$ Alternatively, the modeling of conımercial bank expectations might be approached from a rational expectations perspective. To work along these lines vonld require reference to some kind of structural macromodel, includirg a model of Bundestank behavior. We have not developed such models, and our work is sumewhat more in the spirit of the adaptive expectarions approach (in fact, it is formally equivaleat to the polar version of that procedure, in which the weight on the most receni historical observation is unity). Friedman (1979) has argued that adaptive expectations may be a good approsimation to optimal least squares forecasting. whic $i$ in turn is interpreted as being consistent at least with th spis it of ratio lal expectations. It is in aresting to note, incidentally, that it the rational expectations hypothesis were used in the presint context, a 'strong' or 'semi-strong' version of $i t$, in the sense discussed, e.g., by Shiller $(197 \%$, p. 4), Fischer $(1980$, p. 212 , fn. 2), and others, would have to he applised. In this version, behavior depends on higher moments of the subjective probability dis ribution held by economic units than merely the mean (in the present paper, commercial banks' behavior depends on their pe caption of the variance of the reserve $r$ : in).

${ }^{13} \mathrm{~A}$ similar procedure for representing near-terrn uncertainty has been used recently by other althors, e.g., by Modigliani and Shiller (1973) in their study of the term structure of interest rates. Their approach or sine ted in the vork of Richard Sutch, als evidenced by th: following 


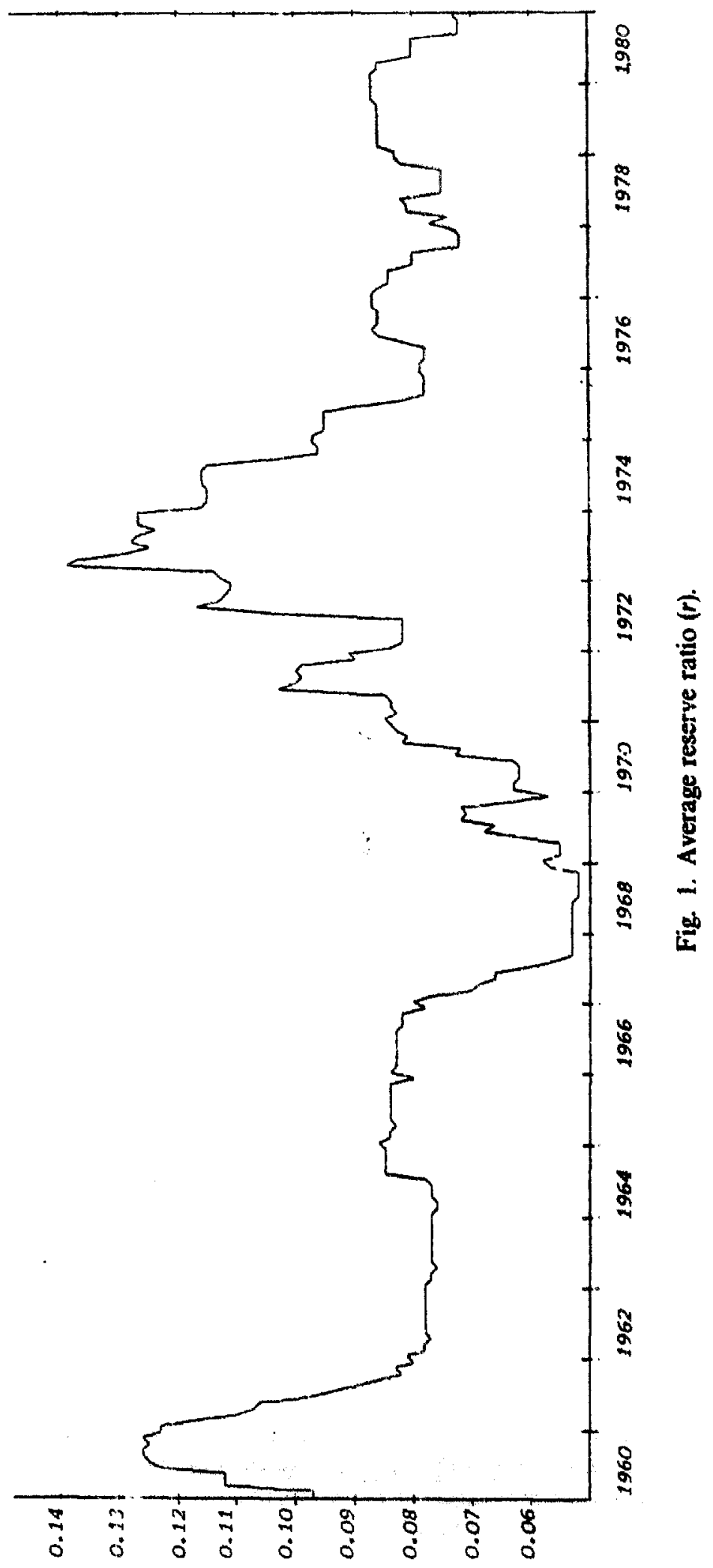


Consequently, we have chosen to represent such expectations for the nearterm future by the variance in the average reserve ratio actually experienced over recent months. ${ }^{14}$ We shall denote this variable $R$; the hypothesis is that the greater is the recently experienced variance in the average reserve ratio, the more variance (or greater uncertainty) will be anticipated for the near future. And the greater the uncertainty about the future, the more free reserves will be held relative to deposits. Since, for a given deposit level, free reserves are valued more highly the greater the degree of uncertainty concerning the future, the variable $R$ can be viewed as a proxy for the subjective 'own yield' on free reserves. ${ }^{15}$

statement in their paper: "In [his unpublished Ph.D. dissertation at the Massachusetts Institute of Technology, 'Expectations, Risk and the Term Structure of Interest Rates', 1968], Suitch hypothesized that if long-term bonds command a positive premium, as they seem to do, then this premium might be expected to rise if there is greater uncertainty about the future course of interest rates - i.e, greater probability that the actual patin migit deviate from the expscted path, described by the expectational model. He further suggested that a reasonable measure of uncertainty might be provided by the variability of the short-term rate in the immediately preceding period. He found that this variable hat the expected pesitive sign and contributed moderately to explaining the movements of the long rate... Following his lead we have, therefore, added to the explanatory variables an eight-quarters moving standard deviation of the commercial paper rate.... [R]esults obtained ty modifications of the bastc specifications uniformly confirm the importance of this variable and yield rather stable estimates of its cocficient. The Sutch hypothesis and approximation receive, therefore, empirical suppori...' [Modigliani and Shiller (1973), pp. 23-24).]

1"We shall argue below that shocks arising frot 1 ther sources (e.g., from changes in the Bundesbank's holdings of foreign exchange, or frorn shanges in net government deposits) do not affect the desired $f_{0} e$ reserve ratio $\lambda^{*}$ but result in changes only in the actual ratio $\lambda$ (see the discussion in section 3.3). For a precise definition of the manner in which the expectational variable $\boldsymbol{R}$ was constructed, see the notes on variable definitions and data sources in the appindix. In specifying $R$ in this way, we are aware that a bank's anticipations regarding future movernents in the average reserve ratio presuma 3 ly entail judgments as to both the amplitude and fequency of such movements. We have not attempted to measure the frequency of changes in $R$ directly. The variable $R$ measures only the amplitude of changes in $r$ but may also embociy frequency considerations indirectly to the extent that there exists a systematic relationship retween the amplitude of reserve requirement changes and their frequency. We have experimented with various time spans in the calculaticn of $R$, but we cound that the results are not very sensitive to this consideration, $t$ least within several months of the span actualiy used (the most recent 18 months). Finally, there are alternative ways of d:picting dispersiou, zuch as the standard deviation or coeficient of variation. We have slicsen the variarce over the standard deviaion only because the statistical results are slightly better in most cases; howe:er, the differences are small and the same qualitative results emerge. We have also carried out e rensive tests using a version of the coefficient of variation. This ariable actually gives slightly better statistical fits than does the variance Ilwiwever, it seems to us that the logic of bank behavior leads to the choice of a pure tneasure of tispersion rather than one scaled by the mean. The notion is that if free reserves basically are fulfilling a buffer-stock function as we hypnthesize, the current or average level of the reserve requirement is of no consequence in making the decision regarding the amount of free reserves to hold. What does tnatter is holding enough free reserves to provide adequate protection against reterve requirement changes.

is Some studies include the rate for ban: jorrowings (e.gg the lombard rate) as an argument in the free reserves function on the grounds that the higher the free reserve ratio, the less likely will be the necessity of borrowing and that the higher is tite tiorrowing rate, the more such protection is desired. In the Federal Republic, changes in the borrowing rate are reflected in change.; in the rate on bank loans and so we have disregarded it in this study. Cf. Cagan (1969, pp. 252-262). 


\subsection{The opportunity cost of holding free reserves}

In an uncertain world, with high potential costs of adjustment to reservi:requirement changes and other shocks and with free reserves functioning primarily as a buffer, we would not necessarily expect the free reserve ratio to respond sensitively to day-to-day variations in some representative shortterm money market interest rate, although this of course rcmains an empirical question which we have tried to address. The problem of measuring the effect of changes in a short-term rate $z$ on the free reserve ratio $\lambda$ is complicated by the fact that some of the assets which comprise free reserves themselves pay a yield which may affect $\lambda$ positively but which may be correlated with $z$. Another complicating factor is that causality runs strongly from $\lambda$ to $z$ as a result of changes in deposits shifting the banks' demand for free reserves for a given supply. ${ }^{16}$ As a practical matter, we have not been able empirically to separate clearly the causal effects of changes in $z$ on $\lambda$ from the feedback effects of changes in $\lambda$ on $z$. To the extent that we included $z$ in our preliminary Iugressions, we found that it generally did not perform well. ${ }^{17}$

${ }^{16}$ This process is shown clearly in the figure, in which the supply of froe reserves is assumed to be fixed at $F R_{0}$, while the demand is assumed to rise due to an increase in total deposits from $D T S F_{1}$ to $D T S F_{2}$. When deposits increase for a given amount of free reserves the free reserve ratio $\dot{\lambda}$ declines, so the consequence of the deposit shift will be an observed $:$ verse movement between $\lambda$ and $z$ However, this reflects causality running from $\lambda$ to $z$, whereas our hypothesis is concerned with the artial effects of changes in $z$ on the demand for free reserves given total deposits (that is, with the slope of the demand curve in the figure).

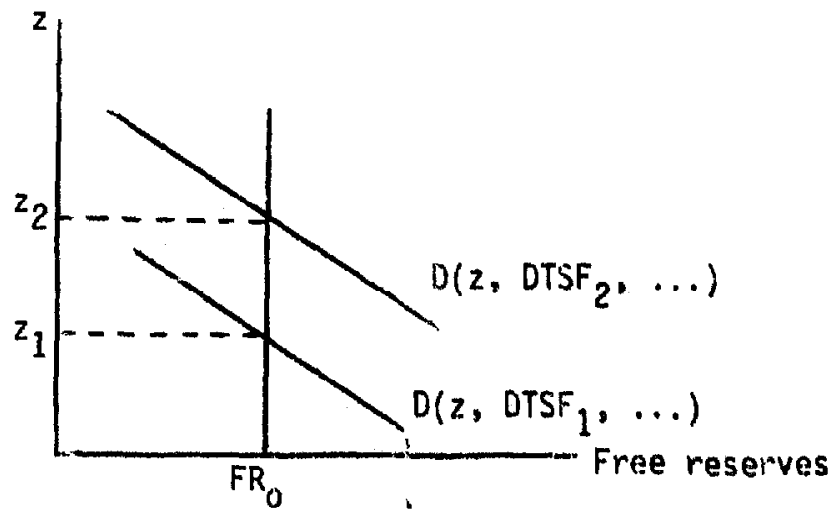

\footnotetext{
${ }^{17}$ Sorne work has recently been done on the causal relationships among the frec reserve ratio, the effective reserve requirement, and the short- and long-term interest rates in the Federal Republic over the two subperiods 1960-1972 and 1973-1978 (timespans which closely match those treated in the present paper) using modern time series methodology. Applying PierceHaugh and Granger causality tests, Baillie, McMahon and Regier (1980) found evidenc: of inverse two-way causality between $\lambda$ and $z$ in $1960-1972$, while for 1973-1978 they reported a significant negative correlation between the two variables at lag zero as well as evidence that past $\lambda$ saused $z$. There is also some evidence presented in this paper inclicating causality trom $\lambda$ to the tong-term interest rate $i$. However, in a subsequent paper by Baillie and McMahon (1981), this latter evidence is shown to be suspect, and it is concluded that... There is no evidence of direct causation from $\lambda$ to $i$. The evidence on sausality between $\lambda$ and $z$ is consistent with he discussion in the text and in footnote 16 above.
} 
However, we do not expect the banking system's free reserve position to be entirely insensitive to opportunity costs. It would appear to us that a longterm interest rate is a more logical measure of these costs than is a monty market iate. If the prime function of free reserves is to aci as a buffer, shieiding banks from the necessity of making unnecessarily frequent and costly adjustments in the longer-term part of their portfolios, then it is reasonable to expect the relevant opportunity-cost variable to be a measure of the yield on longer-term assets in general. $\mathbf{A}$ buffer stock may be seen as a particular type of capital investment. Furthermore, a long-term rate has the additional valuable property of embodying current and expected short-term rates, to the extent that the expectations hypothesis of the term structure of interest rates holds. This is particularly pleasing in the context of an approach like ours, in which the main empinasis is precisely on expectations. In our empirical work we have used the long-term bond rate $i$ as a general measure of the rpportunity cost of holding free reserves. We have not introduced the va itince of the long-tern rate as a determinant of $\lambda^{*}$ because changes in it do $r$ 'st put the banks in the position of having to reacjust their portfolios.

In summary, then, we expect the banking system's desired net free liquid reserve ratio, $\lambda^{*}$, to depend positively on the 'own-yield' variable $R$, reflectıng the buffer-stuck function of these reserves; and negatively on the long-term interest rate, :, summarizing banks' responses to changing opportunity costs:

$$
\lambda^{*}=F(R, i), \quad F_{1}>0, \quad F_{2}<0 .
$$

However, we cannot observe $\lambda^{*}$. The actual free reserve ratio, $\lambda$, embodie; the above considerations but also is affected by (1) the current level of the average reserve ratio $r$, and (2) other disturbances whose effects the Bundesbank and/or the banks themselves may not be able or willing to offset fully. We next consider the treatment of these disturbances.

\subsection{Disturbances affecting free reserves}

The relationship between the observed free reserve ratio and the level of the average required reserve ratio follows directly from our view of free reserves as a buffer stock shielding the banks from unexpected disturbances. Given the current values of $R$ and $i$, the observed free reserve ratio $\lambda$ will tend to move inversely with the average required reserve ratio $r$. Of course, since at least the policy-induced changes in $r$ may be viewed by the banks as being 'permanent', they may respond to some extent to current-period changes in $r$; that is, we would expect the regression coefficient for $;$ to be negative but perhaps smaller than unity, which would indicate partial buffering in this dimension. 
As regards other significant influences, we have included in our regressions two variables which are likely to affect the observed free reserve ratio: changes in the foreign exchange position of the Bundesbank relative to the level of commercial bank deposits, $f x$; and changes in net government deposits at the Bundesbank relative to the commercial bank deposit level, g. ${ }^{18}$

Because of its balance-sheet identity, changes in the Bundesbank's foreign exchange position or changes in net government deposits at the Bundesbank will affect free reserves on a one-for-one basis unless offsetting action is taken (increases in Bundesbank foreign exchange holdings will cause free reserves to rise by the same amount, while increases in government deposits will cause them to fall, ceteris paribus) or unless commercial banks immediately convert such shocks into changes in other portfolio components. ${ }^{19}$

As we have already emphasized, such rapid adjustments are likely to be very costly for banks, and it is precisely to minimize such costs that the banks hold free reserves under our hypothesis. Consequently, we have modeled these influences in such a way that they affect the banks' observed free reserve position immediately and directly (that is, they are absorbed into the free reserves buffer), subject only to possible intervening action by the Bundesbank. That is, if there were no intervention at all, we would expect regression coefficients of +1 and -1 , respectively, for the variables $f x$ and $g$ in a regression explaining movements in $\lambda$. If the Bundesbank has been successful in offsetting exactly the effects of these variables, then (given our assumptions) their regression coefficients should be zero, showing that in those circumstances, they have no systematic effect on free reserves. Coefficients between zero and one in absolute value would suggest partial offsetting if their signs are consistent with prior expectations, while coefficients opposite in sign to the expectations mentioned abcve would suggest overcompensation by the Bundesbank. ${ }^{20}$

It will be noted that movements in the shock variables $f x$ and $g$ do not change the desired free reserve ratio $\lambda^{*}$ in our model, but rather cause the actual value to deviatc from the desired level. If these shocks are absorbed in

\footnotetext{
${ }^{18}$ The Bundesbank also considers these two variables (it refers to them as 'market factors') 10 be of great importance for the explanation of the fluctuations in the actual values of $\lambda_{;} \mathrm{cf} ., 6 . \mathrm{g}$. 'Erläuterungen zur Liquiditätstınalyse der Bundesbank', Monatsberichte der Deutsciun Bundesbank, Juli 1970, p. 35.

${ }^{19}$ Changes in the required reserve ratio $r$ have been considered to be a significant means by which the effects of capitial inflows on bank reserves have been neutralized [cf., e.g., Porter (1972)]. Yet the simple coefficients of determination, using monthly data, $R^{2}\left(r_{t}, f_{t-j}\right), R^{2}\left(r_{t}, g_{t-j}\right)$, $j=0,1,2$ are generally insignificant. The only exception is the period January 1960-June 1966, for which we found $R^{2}\left(r_{t}, f x_{1-1}\right)=0.1, r^{2}\left(r_{t}, f x_{t-2}\right)=013$, values which are rather low but significant. Using quarterly data, we found significant and slightly larger coefficients of determination for this period; the values were $R^{2}(r, f x)=0.27$, and $R^{2}(r, g)=0.19$.

${ }^{20}$ Another logical possibility would be coefficients of the expected sign but larger than unity in absolute value. Such a linding would suggest that Bundesbank action regularly tended to exacerbate the shock rather than offset it, and we view such a finding as unlikely.
} 
free reserves in the same manner as changes in the required reserve ratio, one might expect that variance terms similar to the required reserve ratio variance $R$ should play a role in determing $\lambda^{*}$. We have not constructed our model in this way for the following reasons: First, changes in the required reserve ratio, especially those arising from policy intiatives, are mach more visible to the banks and, in a sense, are felt more widely and immediately than movements in $f x$ or $g$. A sharp increase in the reserve requirement, for instance, will immediately hit all banks and force immediate adjustment by all those without an adequate free reserves cushion. Second, the processes generating changes in $f x$ and $g$ over time are quite different irom the process generating $r$ (and also quite different from each other), as can be seen by comparing figs. 2 and 3 with fig. 1 . In particular, within the subperiods we have used for our regression analysis, the $f x$ series is a random process with a variance which does not vary a great deal within each of these subperiods. ${ }^{21}$ If $f x$ is a stationary random process with roughly constant variance, it should not play a role in the determination of $\lambda^{*}$ parallel to that played by $R$ (beyond appearing implicitily in the intercept of the $\lambda^{*}$ function).

The variable $g$ also exhibits approximately constant variance over the sample subperiods, so there again is no basis for calculating a variance variable for use as a determinant of $\lambda^{*}$. In contrast to $f x$, however, $g$ follows a very predictable pattern dominated by seasonal movernents reflecting flows of government expenditures and tax receipts. In principle, the banks ought to be able to anticipate rather closely the effects on the system's free reserve position of movements in $g$. Whethor or not they react systematically by adjusting other parts of their portiolios will depend on a cost-benefit calculation. We have argued above that the costs of adjustment ate likely to be high, and we view the banks as most likely absorbing movements of $g$ as well as $f x$ in their free reserves buffer.

To summarize, we treat desired free reserves as deiermined by the" "own yield' $R$ (proxied by a variable representing the expected variance in the required reserve ratio) and an opportunity cost variable $i$, the long-term interest rate. The actual free reserve ratio differs from the desired level due to changes in the required reserve ravio $r$ and to otler shocks, here comprised of changes in the foreign exchange holdings of and in net government deposits at the Bundesbank ( $f x$ and $g$, respectively). We assume that banks respond to changes in $R$ and $i$ within the space of one quarter, so that there is, e.g., no dynamic stock-adjustment process going on. Current changes in $f x$ and $g$ eyoke no behavioral response but are absorbed in free reserves. Whatever action is taken by the R:ndesbank in response to these shocks is assumed to be done within the space of one quarter also. The complete

\footnotetext{
${ }^{21}$ We have tested for randomness with a 'runc' test which produc 1 a finding of randomness for $A$ in each of the three subperiods 1960-1966. 1966-1972, and 1973-1980 at the 5 percent confidence level. For a description of this test, see any textbook on non-parametric statistics.
} 


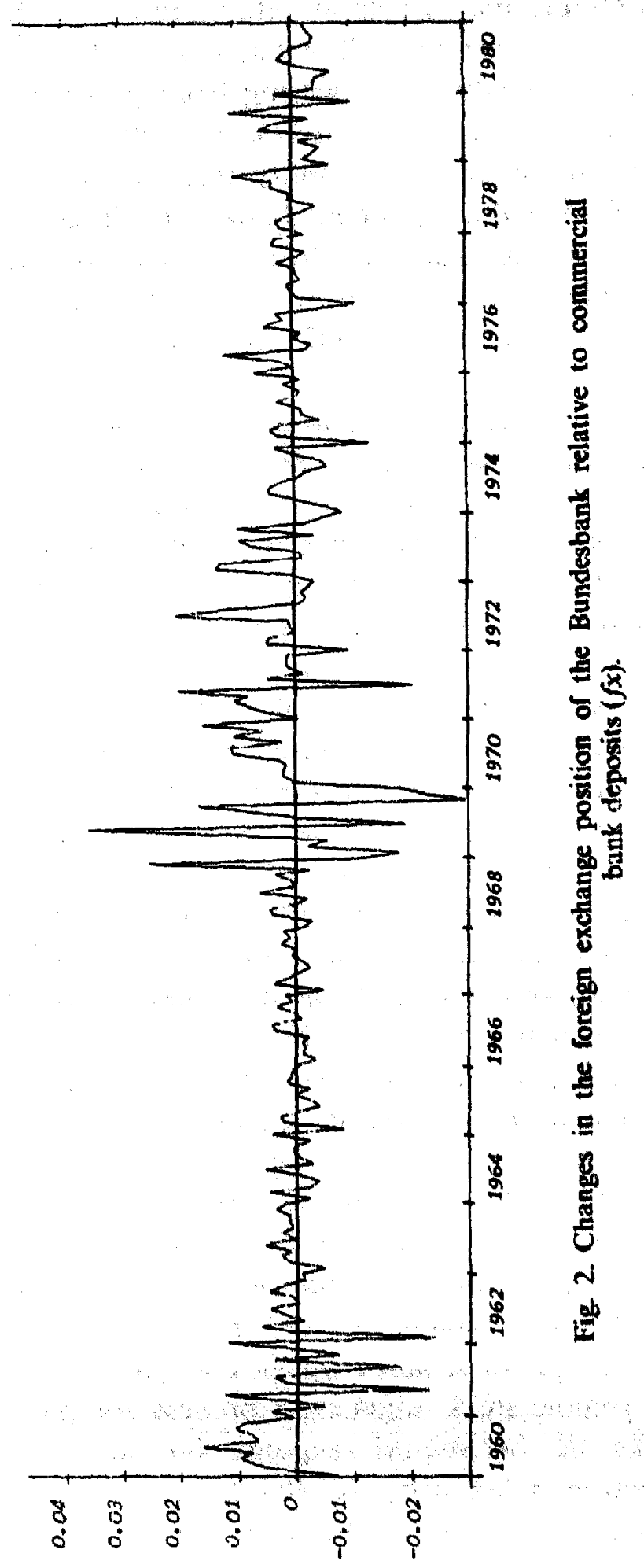




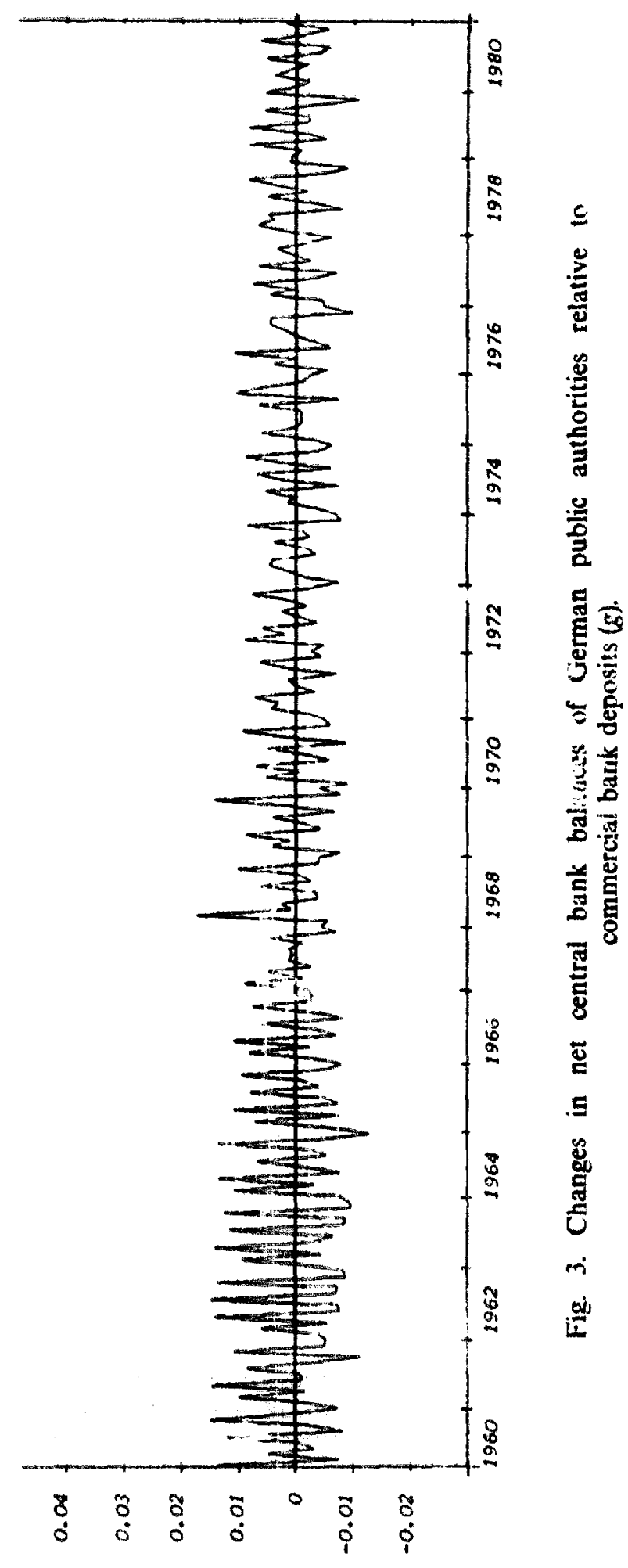


hypothe is may be su marized as follows:

$$
\lambda=f(R, i, r, f x, g)
$$

where $f_{1}>0, f_{2}<0, f_{3}<0$, and the signs of the coefficients of $f x$ and $g$ cannot be deduced a priori. ${ }^{22}$

\section{Empirical results}

We have fitted eq. (2) to the relevant quarterly data for the period 1960$1980 .^{23}$ Due to a number of international and domestic structural changes which occurred in the first part of 1973, separate regressions were done for the period 1960-1972 and for the period since 1973. These changes include the collapse of the fixed-exchange-rate system (with the U.S.\$/DM rate allowed to float as of March 19, 1973); considerable turbulence in financial markets during the first few months of the year; the introduction in June of a new definition of free liquid reserves by the Bundesisank, as mentioned earlier; and abrupt changes during these months in the Bundesbank's policy stance (see fn. 6 above for a brief discussion). This wa:s a period of great uncertainty and of rapid acclimatization by the banks to radically changed circumstances. ${ }^{24}$ We decided to omit the data for January-June 1973 from our tests on the grounds that they do not provide useful evidence for or against our hypothesis, given these considerations. Thus we treat 1973.III1980.IV as a separate subperiod. In addition, in our regressions on the data over 1960-1972, application of the Chow test for stability of the structure generating the data indicated that a structural change had occurred after the

\footnotetext{
${ }^{22}$ Other authors have discussed the role of buffer stocks as a means of redicing uncertainty and avoiding high adjustment custs, and in the banking literature there has been stress laid on the banks need to provide acconimodation for customers and, in general. to foster their relationships with customers over some longer-run horizon and thus to preserve their trustworthiness. Within the broadest context, our hypothesis could be interpreted as a particular instance of 'uncertainty avoidance' as defined by Cyert and March (1963, p. 102), or of 'bounded rationality' [Simon (1975)] or, if one prefers, as the result of some kind of search-theoretical reasoning. In the more particular context of commercial bank decision making, Cagan (1969, p. 260) has noted the need '... to put more emphasis on the long-run goals of successful bank management', and has stated that 'Banks rightly concern themselves with their position in the market over the long run and at all times wish to accommodate the loan demand of their re;gular customers" $(1969$, p. 240). Baltensperger (1980) emphasized the important role of uncertainty, adjustment costs, and informational problems in the decision-making process of the banking firm. As we have stressed, the avoidance of uncertainty and related costs of portfolio adjustment is central to our hypothesis.

${ }^{23}$ We have also done regressions using monthly data. The results were generally similar to the quarterly results, and are not reported here.

${ }^{24}$ For a detailad description of this period see Schlesinger (1977) and Report of the Deutsche Bundesbank for the Year 1973. It should be added that the Bundesbank started its new quantityoriented policy in 1975 (see Report of the Deuische Bundesbank for the Year 1975).
} 
second quarter of 1966 - precisely in the center of the $1960-1972$ sp.n. ${ }^{25}$ This shift is most likely attributable to the increase in foreign exchange inflows in the latter part of the 1960s, coupled with a more activist policy stance on the part of the Bundesbank. As a consequence of thise developments, the commercial banks apparently modified their cwn behavior. Therefore we provide separate estimates for 1960.I-1966.II and 1966.III-1972.IV as well as for 1973.III-1980.IV.

The results of our estimates are reported in table 1. Each of the fits shown there is quite satisfactory by the usual criteria: the signs of the estimated coeficients are in accord with prior expectations, most of the coefficients are significant, and the order of explanation is high. It will be noted that the regrassions do not include lag terms in the determirants of the desired free resirve ratio $\lambda^{*}$, viz. the intere:t rate $i$ and the 'own yield' $R$. This is due to our presuinption that specialize $d$ financial institutions like commercial barks adjust their portfolios rather lapidly in response to changes in the causal variables in question. However, the Durbin-Watsor: statistic for eq. (2.1) indicated the presence of serially correlated regression residuals, so that equation was re-estimated using an autocorrelation procedure which cnabled us to test for autccorrelation up to the third order. ${ }^{26}$ Eq. (2.1) snowed evidence of first-order autocorrelation, while no autocorrelation was evident in the other equations.

The estinates reported in ta:ble 1 are based on seasonally unadjusted data. Alternative regressions including seasonal dummy variables as well as the explanatory variables show? in table 1 were run. Hewever, these regressions were generally somewhat inferior in quality to those done without seasonal dummies, and are not reported here. ${ }^{27}$

\footnotetext{
2.5 Referenee is 10 the test presented in Chow (11)60). The test rejects the null hypothesis that the data were generated by an unchanged structure at the I percent confidence level.

${ }^{26}$ We used the Rth-order Autoregressive Leist Squares (RALS) program developed by Hendry 11972): i brief description of the procedure is given $n$ Scklieper and McMahon (1977, pp. 241ff).

27Introducing seassonal dummy variables alfects $n$, w of the qualitative results except those relating to the net government deposits variable $(g)$ In the second and third subperiods. none of the seasonal dummy variables have significant coeficients. and use of these dummits results in fower -values and smaller estimated coefficients fo the other explanatory variables in absolute value erms) than those cited in table $I$ as well as le wer $\bar{R}^{2}$ values and (for the thirc. subperiod) a substintialy redued Durbin Watson statistic ard insignificance for the gariable. In the estim te over the first subperiod, all of the seasonal durimies have significant confficients while $g$ becories insignificant. A third-order autoregressive stheme appears in the residuals of this regression, the $t$-ratios and the other estimated coefficients increase somewhat in absolute value (indicating. among other things, a substantially greater degree of overshooting by the Bundesbank in : sponse to foreign exchange inapulses (han is shown in table 1), and the $\bar{R}^{2}$ valuc rises slightly. These results suggest that use of the seasonal dummies may introduce multicollinearity into these estimates, especially with regard to the net governuent deposits variable, which itself has a pronounced seasonal pattern. Since we expect $g$ to be causal with respet to $\lambda$ it seems both lozical a priori and rational on the basis of the results ascussed above to prefer the estimates which were obtained without seasonal dummies.
} 


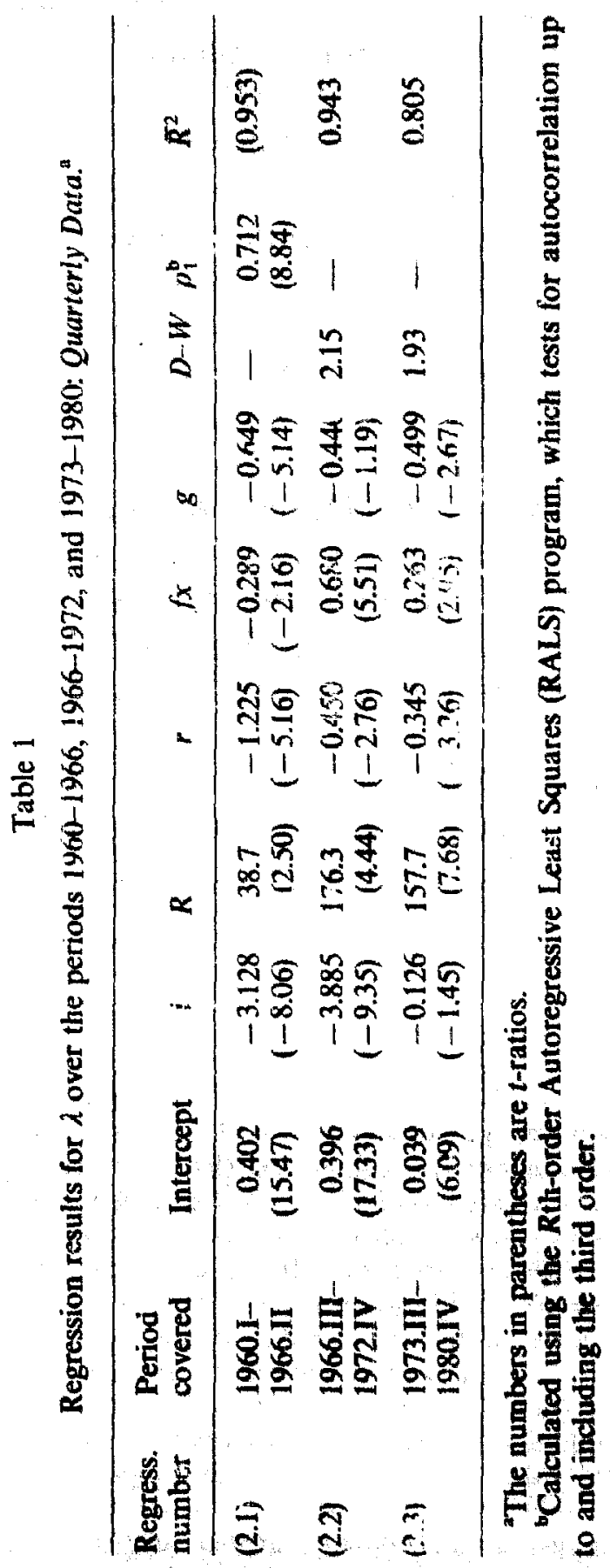


In general, then, the results provide strong empirical support for our hypothesis. Let us now look at some of the details. The estimates show that the long-term interest rate exerts a negative and significant effect on the free reserve ratio during the 1960s; and indeed. the data on elasticities in table 2 indicate that the elasticity of $\lambda$ with respect to $i$ rose considerably in the latter part of the decade (a period during which the average value of $i$ also rose, from 6.33 percent during $1960-1966$ to 7.58 xercent in 1966-1972). After 1973, however, the interest-rate coefficient becomes insignificant and also is greatly reduced in absolute value. We believe this may be a consequence of the sharp reduction in free liquid reserves which occurred at the time of the movement to nexible exchange rates in 1973. With foreign money market instruments no longer included, the mean value of $\lambda$ fell frcm $0.098 \mathrm{ii}$, the 1960-1972 period to 0.0068 during 1973-1980. With a much smaller free reserve cushion available, and with net free reserves being sometimes even Ingative, opportunity costs as expressed by $i$ probably ceased to be of any real importance to the banks.

\section{Table 2}

Elasticities of the net free liguid reserve ratio with respect to its dererminants, based on quarterly regression resulis (calculated at the means).

\begin{tabular}{lllllll}
\hline \multicolumn{5}{c}{ Elasticity of $\lambda$ with respect to } \\
\cline { 2 - 7 } & \multicolumn{1}{c}{$i$} & $R$ & $r$ & $f x$ & $g$ \\
\hline $\begin{array}{l}1960.1- \\
\text { 1966.15 }\end{array}$ & -1.795 & 0.033 & -0.984 & -0.005 & -0.002 \\
$\begin{array}{l}\text { 1966.111- } \\
\text { 1972.1V }\end{array}$ & -3.462 & 0.132 & -0.390 & 0.042 & - a \\
$\begin{array}{l}\text { 1973.111- } \\
\text { 1980.1V }\end{array}$ & - & 1.562 & -4.485 & 0.027 & -0.013 \\
\hline
\end{tabular}

"Elasticity not calculated because regression coeflicient is insignificant. A tabulation of the regression variable means is found in the appendix. In cases where the mean of the independent variable is negative (as for $f x$ and $g$ during 19"31980), the sign of the elasticity agrees with the sign of the regression coefficient.

The estimated coefficients for the expectations variable $R$ are always significant (and increasingly so with the passage of time) and are positive as expected. The elasticity of $\lambda$ with respect to this variable is very small during 1960-1966, \& period when monetary policy was relatively quiescent and when the required reserve ratio did not hange very much or very often. However, the size of the coefficient of $R$ increases in the later subperiods; this, along with the substantial reduction in the average value of $\lambda$ mentioned earlier, produced a fourfold rise in the clasticity of $\lambda$ with respect to $R$ in 1966-1972 
as compared with 1960-1966, and a further twelvefold increase in 1973-1980 as compared with 1966-1972.

While movements in the interest rate and the degree of uncertainty about the future cause the desired free reserve ratio to change, changes in the required reserve ratio $(r)$ and in holdings by the Bundesbank of foreign exchange and of net government deposits relative to total commerial bank deposits $(f x$ and $g$ ) will cause the actual free reserve ratio to deviate from its desired value. All of the subperiod coefficient estimates for $r$ are negative, as expected, and highly significant. The elasticity of the free reserve ratio with respect to this variable has also risen very sharply in 1973-1980 as compared with the two preceding subperiods. However, the coefficient estimate is rather stable in the latter two subperiods, indicating that somewhat less than half of an impulse originating in a change in $r$ shows up as a change in the net free reserve position of the banks. In the first subperiod, approximately the entire shock was buffered in this way. ${ }^{28}$

As to the variables $f x$ and $g$, it has already heen explained that the cnefficient signs will depend on whether the Bundesbank has been less than completely successful in its offsetting operations, or whether it has in fact overcompensated. In the period 1960-1966, there were no serious foreign exchange problems; the negative and significant coefficient estimate for $f x$ suggests that the Bundesbank tended to overcompensate, on the average, for the disturbances that did occur. During 1966-1972, the Bundesbank apparently was able only partially to offset the effects on bank reserves of the much larger changes in its foreign exchange position that took place; the significance of the regression coefficient implies systematic action was taken. According to our estimates, an increase in the Bundesbank's foreign exchange holdings of DM 1 in this period increased free liquid reserves by 68 Pfennig; only one-third of the impact on bank reserves is offset. But in the most recent period, a much higher fraction - about three-fourths - is offset. ${ }^{29}$

During 1960-1966 the Bundesbank responded systematically to changes in net government deposits, according to our results, and was able to offset about one-third of the effect on reserves of changes in these deposits. The degree of offset apparently increased siomewhat in more recent years. Our results indicate that the response coeficient was insignificant for the 19:61972 period, but became significant again in 1973-1980.

\footnotetext{
${ }^{28}$ The estimate of -1.225 for the value of the $r$ coefficient in eq. (2.1) is not significantly different firom - 1 .

${ }^{29}$ Note that our approach is quite different from the offsetting capital nows concept as applied, c.g., by Brunner (1973), Kouri and Forter (1974), and Neumann (1978). Papers like these are based on structural models of the monetary sector, while free reserves, the focus of our paper, are only one component of the monsy supply function Direct compari son of the results may therefore be very misleading. With these reseivations in mind, we note that our results usually indicate some offsetting, even during 1966.III-1972.IV though during that perioc the degree of offsetting achieved was rather small.
} 


\section{Conclusions and implications for policy}

We have shown that movements in the free liquid reserve ratio of the West German commercial banks can be explained very satisfactorily over the whole period 1961)-1930 by a single behavioral hypothesis (though the behavioral coefficients change in value in the mid-1960s, due probably to the increased impor ance of international monetary disturbances and the more active policy stance adopted by the Bundesbank; and in 1973, again because of marked changes in the internationial monetary environment and in the focus of Bundesbank policy). The determinants of the desired free reserve ratio appear to have been a measurc of opportunity costs (the long-term bond rate), which howezver has become considerbiy less important in recent years than earlier; and a measure of uncertainty about the future which we interpret as a proxy for the expected 'own yield' on free liquid reserves. This latter variable has increased very considerably in importance over the sample period and its use is probably the main innovation in our work.

To explain differences between the desired (lorig-run) and actual free reserve ratios, we used the actual required reserve ratio and changes in Bundesbank holdings of foreign exchange and of net government deposits at the central bank. As expected, movements in the required reserve ratio were related inversely to the free reserve ratio, ceteris paribus. Our results show that the Bundesbank has had mixed success in its attempts to neutralize the effects of the other disturbances on free reserves. but in the most ecent subperiod it has been able to offset about three-fourths of the effect of foreign exchange disturbances and about one-half of the effect of changes in government deposits.

Our findings have a further interesting implication for the conduct of monetary policy in the Federal Republic. It has been the Bundesbank's practice to attempt to influence free reserves and the money supply chiefly by active use of the required reserve ratio; and fig. 1 shows that the pattern of movement in $r$ has not been very stable. Our results suggest that, in a sense, this strategy nay be partially self-defeating: we found that changes in the variance over time of the required reserve ratio muduced ch.nges in the banks' desired tree reserve position and presumably in the supply of money and credit. Thus an activist policy .... that is, a policy under which the variance of the required ceserve ratio changes frequently - will cause changes in the desired free reserve ratio and in the variables which depend on it. To put it in the opposite way: ceteris paribus, our findings show that the variance of the iree reserve ratio, and presumably eventually of the money supply, would be reduced it the movements of the required reserve ratio were kept within a given constant range. Most specifically, for given values of the other variables determining the desired free reserve ratio, and abstracting from the eftects or shor's, a particular free reserve target could in 
principal be achieved by keeping the variance of the requireci reserve ratio within the appropriate range.

Appendix 1: Means of regression variables (quarterly data)"

\begin{tabular}{|c|c|c|c|c|c|c|}
\hline & $i$ & $R$ & $r$ & $f x$ & $g$ & r. \\
\hline $\begin{array}{l}1960.1- \\
1966.1 I\end{array}$ & $\begin{array}{c}0.06328 \\
(0.0049)\end{array}$ & $\begin{array}{l}0.93465 \cdot 10^{-4} \\
(0.0195)\end{array}$ & $\begin{array}{c}0.08859 \\
(0.0157)\end{array}$ & $\begin{array}{c}0.00190 \\
(0.0105)\end{array}$ & $\begin{array}{l}0.00026 \\
(0.0055)\end{array}$ & $\begin{array}{c}0.11030 \\
(0.0223)\end{array}$ \\
\hline $\begin{array}{l}\text { 1966.III- } \\
\text { 1972.IV }\end{array}$ & $\begin{array}{c}0.07581 \\
(0.0070)\end{array}$ & $\begin{array}{l}0.63676 \cdot 10^{-4} \\
(0.0050)\end{array}$ & $\begin{array}{c}0.07372 \\
(0.0179)\end{array}$ & $\begin{array}{c}0.00522 \\
(0.0137)\end{array}$ & $\begin{array}{l}0.00029 \\
(0.0047)\end{array}$ & $\begin{array}{r}0.08507 \\
(0.0307)\end{array}$ \\
\hline $\begin{array}{l}\text { 1973.III- } \\
\text { 1980.IV }\end{array}$ & $\begin{array}{c}0.08144 \\
(0.0150)\end{array}$ & $\begin{array}{l}0.67653 \cdot 10^{-4} \\
(0.0680)\end{array}$ & $\begin{array}{c}0.08881 \\
(0.0152)\end{array}$ & $\begin{array}{c}-0.00070 \\
(0.0095)\end{array}$ & $\begin{array}{c}-0.00018 \\
(0.0045)\end{array}$ & $\begin{array}{r}0.00683 \\
(0.0084)\end{array}$ \\
\hline
\end{tabular}

The numbers in parentheses are standard deviations.

Appendix 2: Notation and data sources

D -Demand deposits (Monthly Report of the Deutsche Bundesbank (MORE: Table 1.2).

DTSF - Total volume of non-banks' deposits (equal to the sum of $D, T, S$, F).

F -Foreign deposits (1960-1968 including Deutsche Bundesbank) (MORE: Table 1.2).

$F R \quad-$ Free liquid reserves.

(1) Jan. 1960-Dec. 1972 (net free reserves) equal to the sum of - excess reserves (banks' central bank balances less the required minimum reserve),

- domestic money market papers (Treasury bills and discountable Treasury bonds of the Federal Government, its special funds and the Länder Governments, Storage Agency bills, prime bankers' acceptances, bills with Limit B accorded to the Export Credit Company, mobilization and liquidity paper to the extent that it is included in the Bundesbank's money market regulating arrangements),

- foreign money market investments, and

- unused rediscount quotas, minus

- lombard credits.

[MORE (Dec. 1972): Table I.3.]

(2) July 1973-Dec. 1980 (net free reserves) equal to the sum of

- excess reserves,

- domestic money market papers, and

- unused rediscount quotas, ${ }^{a}$ minus 
- lombard credits (including special lombard creditis), minus

- trade bills tought under repurchase agreements on the open market.

(a) (Deutsche Bundesbank, unpublished).

(b) MORE: Table II.1.a).

(3) July 1973-Dec. 1980 gross free reserves) equal to the sum of

- excess reserves,

- domestic money market papers, and

- unused rediscount quotas.

(Deutsche Bundesbank, unpublished.)

FXBB - Net foreign assets of the Deutsche Bundesbank (MORE: Table IX.6.A).

$\triangle F X B B$ - Quarterly changes in $F X B B, \triangle F X B B_{t}=F X B B_{t}-F X 3 B_{t-1}, t=$ $1, \ldots, T$, where $t$ denotes the quarter; $F X B B_{t}, F X B B_{t-1}$ are the quarterly averages of monthly data of the respective quarter $t, t-1$.

$G X B B$ - Net central bank halances of German public authoritics Federal Government, Länder Governments, Equalization of Burdens Fund and ERP Special Fund) equal to: Current deposits of German public authorities minus cash advances to German public authorities by the Deutsche Bundesbank. (MORE: Table II.1.)

$\triangle G X B B$ - Quarterly changes in $G X B B, \triangle G X B B_{t}=G X B B_{t}-G X B B_{t-1}, t=$ $1, \ldots, T$, where $t$ denotes the quarter; $G X B B_{t}, G X B B_{t-1}$ are the quarterly averages of monthly data of the respective quarter $t, t-1$.

$i \quad-$ Yield on bonds in circulation (MORE: Table VI.t; monthly averages).

$r \quad$ - Average reserve ratio (MORE: Table IV.2.c; monthly averages) (in March 1978 the method of computation was changed: Reserve requirements before subtraction of deductible vault cash balances).

$S \quad-$ Savings deposits (MORE: Table I.2).

$T \quad-$ Time deposits (MORE: Table 1.2).

$\lambda-F R / D T S F$, where $F R, D T S F$ are the quarterly aierages of monthly data of the respective quarter.

$f x \quad-\triangle F X B B / D T S F$, where DTSF is the quarterly average of montlily data of the respective quarter (equal to the denominatoi DTSF of quarterly $\lambda$ ).

z $-\triangle G \times B B / D T S F$, where $D T S F$ is the quarterly average of monthly data of the respective quarter (equal to the denominator DTSF of quarterly $\lambda$ ).

$R \quad-\operatorname{var}\left(r_{t}\right)=1 / N-1 \cdot \sum_{j=0}^{N-1}\left(r_{i}-1,1-\bar{r}_{i-1}\right)^{2}$, calculated on a monthly basis where $N=18$ (months),

$$
\bar{r}_{t-1}=\frac{1}{N} \cdot \sum_{j=0}^{N} r_{t-j-1}
$$


Remarks - MORE: Monthly Report of the Deutsche Bundesbank. Table . unbers refer to MORE December 1979. If not otherwise specified,

- monthly data are always end-of-month data,

- quarterly data are always quarterly averages of monthly data, as specified, of the respentive quarter.

\section{References}

Baillie, R.T. and P.C. McMahon, 1981, Multivariate causality and the relationship between the free liquid reserves and interest rates, Zeitschrift für die gesante Staatswissenschaft 137 , forthcoming.

Eaillie, R.T., P.C. McMahon and H.J. Regier, 1980, Causality and free liquid reserves in the Federal Republic of Germany, Zeitschrift für die gesamte Staatswissenschaft 136, 642-657.

Baitensperger, E, 1980, Alternative approaches to the theory of the banking firm, Journal of Monelary Economics 6, 1-38.

Brunner, K., 1973, Money supply process and mosetary policy in an open ecoriomy, ir: M.B. Connolly and A.K. Swoboda, eds., International trade and money (Allen and Unwin, London) 127-166.

Cagan, $P$, 1969, Interest rates and bank reserves - A reinterpretation of the statistical association, in: J.M. Guttentag and P. Cagan, eds., Essays on interest rates, Vol. 1 (National Bureau of Economic Research, New York) 223-271.

Chow, G.C, 1960, Tests of equality between sets of coefficients in two linear regressions, Ecor ametrica 28, 591-605.

Cyert, R.M. and J.G. March, 1963, A behavioral theory of the firm (Prentice-Hail, Englewood Clifis, NJ).

Deutsche Bundextank, Monthly report of the Deutsche Bundesbank, various issues.

Deutsche Bundesbank, 1971, Instruments of monetary policy in the Federal Republic of Garmany (Frankfurt).

Deutsche Bundesbank, 1980, Die währungspolitischen Institutionen und Instrumente in der Buncosirepublik Deutschland, 3. überarb. Aufl. (Frankfurt).

Fischer, S., 1980, On activist monetary policy with rational expectations, in: S. Fischer, ed., Raticral expectations and economic policy (University of Chicago Press, Chicago, IL) 211... 235.

Friednan, B.M., 1979, Optimal expectations and the extreme information assumptions of 'rational expectations' macromodels, Joumal of Monetary Economics $5,23-41$.

Hendry, D.F., 1972, Users manual for KALS: The estimation of linear equations with lagged dependent variables and autoregressiva errois, unpublished paper (London School of Economics, London).

König, H., W. Gaab and J. Wolters, 1977 , An econometric model of the financial sector of the Federal Republic of Germany, in: S.F. Frowen, A.S. Courakis and M.H. Miller, eds, Monetary polioy and economic activity in West Germany (Gustav Fischer Verlag, Stuttgart New York) 157-186.

Kouri, PJ.K. and M. Porter, 1974, International capital flows and portfolio equilibrium, Journul of Political Economy 82, $443-467$.

Meigs, A.J., 1962, Free reserves and the money supply (The University of Chicago Press. Chicago, IL).

Modiglian, $F$. and R. Shiller, 1973, Inllation, rational expectations and the term structure of interest rates, Economica $40 \mathrm{~ns}, 12-43$.

Neumann, M.J.M., 1978, Konterkartierende Kapitalbewegungen, eine Oberprüfung der deutschen Evidenz, Kredit und Kapita1 11, 348-364.

Porter, M.G, 1972, Capital flows as an offet to monetary policy: The Cierman experience, International Monetary Fund Staff Papers 19, 395-424,

Richter, R., P.C McMahon and H.J. Regier, 1978, Determinants of free liquid reserves in the 
Federal Republic of Germany 1960-1972, Zeitschrift für die gesante Staatswissenschaft 134, 686-703.

Schiesiuget, 1.. 1977, Recent developments in West Gernaan monetary policy, in: S.F. Frowen, A.S. Courakis and M.H. Miller. eds., Monetary policy and economic activity in West Germany (Gustav Fischer Verlag, Stuttgart-New York) 1-12.

Schlieper, U. and P.C. McMahon, 1977, Dynamic multipliers and the trade balance, in: S.F. Frowen, A.S. Courakis and M.H. Miller, eds., Monctary policy and economic activity in West Germany (Gustav Fiecher Vertag Stuttgart-New York) 233-245.

Shiller, RJ. 1978, Rational expectations and the dynamic structure of macroeconomic models, Journal of Monetary Economics 4, 1-44.

Simon, H., 1957, Models of man (Wiley, New York). 